\title{
Implementation Kato Mandaki of Civility Minangkabau Community in Rangkasbitung
}

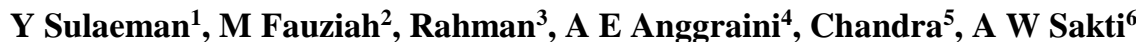 \\ $\left\{{ }^{1}\right.$ yenisulaemananesta@gmail.com, ${ }^{2}$ kfauziah19@upi.edu, ${ }^{3}$ rahmanprofupi@upi.edu, \\ 4adeekaanggraini@gmail.com, ${ }^{5}$ chandra@ fip.unp.ac.id, ${ }^{6}$ achiewibawasakti@gmail.com\}
}

\author{
${ }^{1,2}$ STKIP Syekh Manshur Pandeglang, Indonesia \\ ${ }^{3,4,6}$ Universitas Pendidikan Indonesia Bandung, Indonesia \\ ${ }^{5}$ Universitas Negeri Padang, Indonesia
}

\begin{abstract}
Merantau activities is a tradition of Minangkabau people who are one of the cultural richness in Indonesia. The area that is the destination of Minangkabau merantau is the island of Java. This research aims to know how to implemenation Kato mandaki of the Minangkabau community in Rangkasbitung. The local wisdom in Minangkabau one of them kato nan ampek consisting of kato mandaki, Kato Mandata, kato Manurun, and kato Malereng. Minangkanbau people's speech acts has rules according to their speak opponents. The use of kato mandaki used as a form of communication for the Minangkabau people with the opposite speak is a person who is larger or elder. This research is research qualitative descriptive study in which writers conduct interviews and observations on Minangkabau communities residing in Rangkasbitung
\end{abstract}

Keywords: Kato Mandaki, Civility, The Minangkabau Community In Rangkasbitung

\section{INTRODUCTION}

Indonesia with multiculturalism has local wisdom and its own culture in each region. West Sumatra Province has a lot of local wisdom and a very unique culture. One interesting culture is wandering. Wandering activities become a culture and tradition in West Sumatra, known as the Minangkabau. This wandering activity will cause some changes due to the cultural influence of the place to wander. The area which is the main destination of the Minangkabau people to migrate is Java.

The culture of the Minangkabau community and the Sundanese community is different. Judging from the politeness of language, language, and so forth. In Minangkabau, his politeness is a local wisdom called kato nan ampek. Where the Minangkabau people arranged the way to speak according to the other person. Kato nan ampek consists of kato mandaki, kato malereng, kato mandata, and kato manurun.

The implementation of Minangkabau people politeness is a form of preservation and cultural preservation. The application of Kato Nan Ampek's values in social life to the present day society is still polite in behaving, acting and calling to the elderly as well as teenagers can distinguish the way of behaving well to the greater, equally large And the same small both in 
the family and in everyday life, Awengki[1] . The increasing number of Minangkabau people on Java makes the writer interested in knowing whether these overseas people still apply politeness and teach their children who have higher social interaction with the local community. Get to know their culture and traditions. The purpose of this study is to find out whether the overseas community still maintains and /or teaches about the politeness of speaking Minangkabau people, and how to maintain it and/or teach it in the city of Rangkasbitung which is thick with Sundanese culture.

According to Nisa [2] that the internalization of character values in the contribution of duo baleh donations for students from Minangkabau can try to preserve and activate it as a manifestation of their love for Minang culture.

Based on the above opinion it can be concluded how high the sense of love of culture and traditional rules of the Minangkabau society. For this reason, researchers about the implementation of kato mandaki in the city of Rangkasbitung, Minang community.

The research was conducted in the city of Rangkasbitung as the subject of research, namely the original Minangkabau people in this city. The number of nomads from West Sumatra province who live and live in Rangkasbitung makes the writer want to know the culture and what changes I have made that appear in politeness.

The author raised the presentation of kato mandaki politeness in Rangkasbitung because of seeing from people who use Minang language while in their stalls, on the market they use Minangkabau language. So the authors are interested in exploring and exploring how their children go to school and socialize with local/native Rangkasbitung people who use Sundanese.

The use of language is good in a family environment besides, the use of complete sentence with commonly chronological order is indicating the politeness. The less complete sentence with inverisive order reflects the impoliteness which was concluded G. Fahmi[3]. So that researchers can conclude that it is necessary to use good and structural words.

Modesty, Brown and Levinson [4] which states that politeness is a fundamental thing in pragmatics because politeness is a universal phenomenon in the use of language in social contexts. The importance of students' politeness in the learning process is a form of context in which language Diani [5] concluded the speech of students who adhere to the maxim of wisdom, maxim of generosity, maxim of appreciation, maxim of simplicity, maxim of consensus, and maxim of sympathy.

Kato Mandaki is used by interlocutors who are younger to the older based on sex, kinship using the word call or pronoun person

Merantau At Naim [6], [7] Merantau explaining the origin of the word "merantau" itself comes from the Minangkabau language and culture of "rantau". Rantau was originally meaningful: the territory which was outside the core region of Minangkabau (the place of origin of the Minangkabau civilization). The Minangkabau civilization experienced several periods or ups and downs. The core area is called "darek" (land) or luhak nan Tigo. Merantau is a pattern of separation from the area of origin to another area, but with its own desires or the community leaves the hometown without orders or advice from anyone with their respective goals.

Navis [8], Yufian [9], and Ermaneli [10] explain kato mandaki is a language used by someone to someone who is older (age) or older who must be respected or respected. Kato mandaki is used by interlocutors who are younger to the older based on sex, kinship relations using the word call or person pronoun as follows:

a. $\quad$ Parents use pronouns amak, bundo, mande, amai, and ama.

b. The sisters use pronoun uni, uniang, one, onang, and so on. 
c. To the younger sister of the father and mother the pronoun etek or mak etek, uncu or mak uncu. Furthermore, the older sister of the father and mother substitute for odang (large) or amak odang, ongah (middle) or mak angah

d. In the parents of women, fathers and mothers are called amak, mate, uwo, enek, and so on.

e. In male parents using pronouns abak, buya, abah, apa, ayah, and so on.

f. The brothers use pronouns uda, Tuan, Ajo, Atak, abang, and so on.

g. For the younger brother of the father and mother, the substitution word for Pak etek or etek, om or om. Next, the older brother of the father and mother, the substitute for Pak Odang or Mak Odang, are you or not

h. In the parents of men, the father and mother were called abak, angku, old father, dan grandfather.

Kato mandaki is intended for younger interlocutors who are older/older as a form of respect for someone's rank or position such as the president, sir datuak, the governor, the colonel, sir ustad, the teacher and so on.

The most influential theory of politeness is the theory formulated by Brown and Levinson[4] which states that politeness is a fundamental thing in pragmatics because politeness is a universal phenomenon in the use of language in social contexts.

That is also the case with the use of the kato style as stated by Syofiani [10] which is often not used in an appropriate situation. The rationale in the discussion of this kato style refers to the concepts of communication, both local and general in nature.

Furthermore, Chea et al. [11], Emely [12] stated the type of politeness. The politeness of kato mandaki is one form of verbal politeness, namely the concept of verbal language politeness refers to all aspects of verbal communication. Oral politeness is a two-way communication that applies directly in conversation.

Furthermore Efrianto [13] argues that politeness in demand; implemented in the nan ampek, then the politeness of demand in the Minangkabau language is manifested in pragmatic (Lii) and suprasegmental aspects, and kinesik. Linguistic politeness is characterized by the use of the word toloang, and the use of appropriate greetings.

Kato mandaki and politeness address the level of one's communication skills. Courtesy when communicating is very important as Wood in Rahman [14] explains that communication skills greatly affect a person in adapting to the environment.

The findings of this study showed that there were students' utterances that complytact maxim, generosity maxim, approbation maxim, modesty maxim, and sympathy maxim [5] For that communication skills kato mandaki migrant community is still maintained because of the consistency of activities and groups of Minangkabau people in Rangkasbitung which is still very high. in line with the results of the study the results show that there is tact maxim, modesty maxim, agreement maxim, approbation maxim, and sympathy maxim[15]

\section{RESEARCH METHOD}

This study uses a descriptive qualitative approach. The instrument sheet that has been used can answer the research objectives to find out whether and how to implement kato mandaki against the politeness of the Minangkabau nomads in Rangkasbitung. Data collection uses sheets of observation instruments and interviews which are then described based on the information obtained from the speakers about the implementation of kato mandaki in the politeness of the Minangkabau nomads in Rangkasbitung. 


\section{RESULTS AND DISCUSSION}

The research carried out explained that the implementation of kato mandaki towards the politeness of the Minangkabau nomads in Rangkasbitung was still maintained because in the family still applied the rules that apply in the area of origin namely Minangkabau. Calls used to older people are still in accordance with Minangkabau culture. The Pangilan they used to join their relatives who lived / lived in Rangkasbitung using a call that became the rules of the Minangkabau. Minangkabau people explain how they maintain the rules of speech while still using their culture both within the family and within the Minangkabau nomadic community groups. So that their children while at home and the IKM (Minangkabau Family Association) group are obliged to use language and preserve their culture. While in the school environment and playing it. Their children are not restricted because in a day the average child socializes with the local environment in one week for only 45 hours out of 168 hours.

In everyday life they apply the use of rules and greetings like when they are at home: a child with a father or mother, a sister to an older sibling may not be high but by using words with respect. Yulfian [9] there is a saying of customary customs that explains the rules for using kato mandaki "“turuik pangaja urang tuo, supayo badan nak salamaik, langkah. Babaliak, sasek suruik, baitu paham kito hendaknyo, pangaja rang tuo jiko dilangga, cilako badan kasudahannyo"(Follow the teaching of the parents so that the body wishes to survive the wrong steps, return; If the recuperation is so understanding we should teach parents if violated woe to the body of the end)

Kato mandaki is a greeting when communicating verbally addressing politeness which is shown as a form of respect, attention and keep the advice of those who are older than us wholeheartedly; when given responsibility, do the task happily; obey the orders of parents; greeting parents and older people when meeting and on certain days; make it a habit to receive and give something from other people with your right hand; make it a habit to say the word thank you; always say goodbye when leaving home with someone at home

Kato mandaki is still applied in the nomads' community. Where based on the instruments that the authors collected stated that when they gathered together Minangkabau people their children still used the rules that apply in Minangkabau. Greetings are used as in the area of origin or they hold regular monthly meetings in either the IKM group or their respective regional groups. Even though they are in the overseas region. The purpose of meeting activities in the form of social gathering or other is one of the ways to preserve Minangkabau culture to their children or a manifestation of introducing their hometown. So that the cultural values and local wisdom that become distinctive values and only exist in the Minangkabau are maintained

The results of this study the authors discussed with several community leaders who were monitored as a number of figures who have long lived and lived in the city of Rangkasbitung revealed that the implementation of kato mandaki towards the politeness of the Minangkabau migrants in Rangkasbitung is still very thick and not influenced by local culture So the rules for using kato mandaki on the politeness of Minangkabau nomads in communication are still very high. This is evidenced by the use of the Minangkabau language also does not fade by the local language (Sundanese) and the ease of recognizing the dialect of the Minangkabau language that is more thick and the original greeting used (Uni, Uda, Ajo, Datuak, and others) while on the market. 


\section{CONCLUSIONS}

The conclusion of the results of this study, namely: a. The use of the kato mandaki of the Minangkabau migrant community in Rangkasbitung is still very high and is used by every migrant family. So that their children's communication politeness is still full of Minangkabau local wisdom; b. By applying the Minang language in their daily communication and regular monthly activities with Minangkabau people (West Sumatra) through the IKM (Minangkabau Family Association) where they will implement the rules and greetings in accordance with the rules of politeness in Minangkabau. Greetings according to the rules of kato mandaki.

\section{REFERENCES}

[1] AWENGKI, "Forms Implementation Values Kato Nan Ampek In Pasukuan Caniago In Jorong Tangkit Nagari Ampang Kuranji Koto Baru District Dharmasraya Regency," STKIP PGRI Sumatera Barat, 2017.

[2] N. Islami, "Internalisasi Nilai-Nilai Karakter dalam Petuah Sumbang Duo Baleh bagi Mahasiswi Asal Minangkabau di Kota Purwokerto Tahun 2016," in International Conference Of Moslem Society, 2016, vol. 1, pp. 44-59.

[3] G. Fahmi, "Wujud Kesantunan Berbahasa Mahasiswa terhadap dosen di STAIN Kendari," Arbitrer, vol. 1, no. 1, pp. 8-18, 2013.

[4] S. Brown, P., \& Levinson, Universals of Language Usages: Politeness Phenomena; in: Esther Goody (ed.), Questions and Politeness Strategies in Social Interaction. Cambridge. Cambridge: Cambridge University Press, 1978.

[5] W. W. Diani Febriasari, "Kesantunan Berbahasa Dalam Proses Pembelajaran Di Sekolah Dasar,” J. Kredo Vol. 2 No. 1 Oktober 2018, vol. 2, pp. 140-156, 2018.

[6] M. Naim, "Merantau," merantau, 1974. [Online]. Available: https://id.wikipedia.org/wiki/Merantau. [Accessed: 06-May-2019].

[7] A. A. Suryadinata, Leo, E N Arifin, "No Indonesia's Population: Ethnicity and Religion in a Changing Political LandscapeTitle," ISEAS, 2003.

[8] N. A.A, Alam Takambang Jadi Guru, Adat Kebudayaan Minangkabau. Jakarta: PT Mutiara Sumber Widya, 1986.

[9] Yulfian Azrial, Budaya Alam Minangkabau kelas III SD. Padang: Angkasa Raya, 1998.

[10] Ermaneli, Budaya Alam Minangkabau Kelas III SD. Padang: Jasa Surya, 2011.

[11] Chea Kah Kei; Tan Jia Qi and Tea An Qi, "Bentuk dan Jenis Kesantunan Berbahasa," 7 september, 2015. [Online]. Available: http://threecheese1997.blogspot.com/2015/09/bab-3.html . [Accessed: 04-May-2019].

[12] Emily Wong, “Kesantunan.," 12 September, 2015. [Online]. Available: http://emilywong1211.blogspot.my/2015/09/bab-3-bentuk-dan-jenis-kesantunan.html. [Accessed: 04-May-2019].

[13] Efrianto and Afnita, "The Politeness Of Bungo Pasang Language Using Kato Nan Ampek In Minangkabau,” J. Kata Penelit. tentang Ilmu Bhs. dan Sastra, vol. 3, no. 1, pp. 58-75, 2019.

[14] Rahman;Wahyu Sopandi; Rani Nurcita; Rasi Yugafiati, "Literasi Dalam Konteks Keterampilan Komunikasi Abad 21 Pada Mahasiswa Pendidikan Guru Sekolah Dasar," Bandung, 2018.

[15] F. S. Cahyaningrum, "Students' Language Politeness Within Negotiation Context In Senior High School,” J. pena Indones., vol. 4, pp. 1-23, 2018. 
[16] K. Saddhono, "Language of Coastal Communities in the Northern Coast of Central Java: Sociolinguistic Studies in Cultural Integration Maritime-Agrarian Perspective." Adv. Sci. Let. vol. 23 no.10 pp 10054-10056, 2017 